\title{
Evaluating Equal Education Certification for Indonesian Formal Education by Using CIPP Model
}

\author{
Nurkhasanah, Ahmad Sofyan, Hasyim Asy'ari \\ Syarif Hidayatullah State Islamic University Jakarta, Jl. Ir. H. Djuanda 95, Ciputat, Indonesia \\ Corresponding e-mail: nurhasanahsmart081@gmail.com
}

\begin{abstract}
Paket $C$ is government program aims to providing equal education certification for Indonesian who are not able to finish their formal education. The evaluating Paket $C$ program using CIPP model; Context, Input, Process, and Product dimension with a qualitative approach. The evaluation findings on the context dimension is high enough on the administrative aspects required but not in detail regarding to the guidelines of implementing the Paket $C$. The input dimension is low enough on the competence of six tutors, consist of two tutors who have educational relevance whereas one tutor who does not have a qualification of bachelor degree. The process dimension on the results are low enough in managerial systems and have inappropriate procedures such as limitations of class and area of land and tutors time as well as the curriculum used based on the needs of the National Exam. The product dimension are fairly high even though the national exam score for 3 years ago has decreased, but the graduates have changed the work better, and existence of the Paket $C$ for the community gains a positive response. Based on findings, it is recommended that the Paket $C$ program needs to be continued. It is advisable in the development of the program, new strategy need to be built based on the strong research and the relevant context of government. It needs to provide a detailed guidance on the learning organization, regular training in managerial system and tutor in the academic system. The foundation, conducted regular meetings and evaluations between managers, tutors and technical speakers as well are needed as the management improvements. The tutors, it needs to utilize tutorial and self-learning. The evaluators should pay attention to aspects of context such as needs and expedience analysis program. Therefore the idealism can appear in education.
\end{abstract}

Keywords: program evalution, CIPP, Paket $C$, compulsory of education

\section{INTRODUCTION}

Various problems arise in our education system. There are consist of first, low quality or quality education. Second, is the absence equity in gaining access in the field education. Third, is the absence efficiency in the organization of education. Besides that the fourth problem is the absence of democratization of education, role and society in education still very limited.

The importance of education for every citizen has been stated in Law of National Education System No. 20, 2003 article 5 affirms that "Every citizen has the same right to obtain quality education. The national education system seeks to ensure equal distribution of education, quality improvement and the relevance and efficiency of education management to address the changing demands of local, national and global life, so that the quality of education needs to be improved."

However, not all citizen is able of afford to take formal education. According to 2015 data publish collaboratively by Ministry of education and culture, UNESCO and UNICEF, all Indonesian children $(100 \%)$ make their elementary education. Yet, the higher the education level, the lower the percentage of citizens who are able to finish. The children enter elementary school until graduation totally $80 \%$, then the less of has been drop out from school. The students continued to junior high school 
totally $61 \%$ and graduated amount to $48 \%$ and then students of senior high school totally $21 \%$, then graduated amount to $10 \%$. Whereas the students continuing college totally $1.4 \%$. Other that, The reasons of citizens not continuing their education vary, among which are financial limitation, time restrictiveness (opportunity and aged), and distance.

It is the reasons, wherefore the government is seeking non-formal education to complement the formal education presence by completing the 12 years compulsory education of Paket $C$ pogram is equivalence paket. Paket $C$ program was formed with the aims of treat exhaustively 12 years old as well as helping the government to level education, become a real society legally because it works and is beneficial to the community and is considered mature, aids that are not formal education because there is no age limit for non-formal education, and learners can proceed to higher education.

Every program launched by the government certainly has advantages and disadvantages of each. To realize a quality non-formal education it needs to be evaluated thoroughly.

\section{METHODS}

Qualitative approach was used to evaluate paket $C$ program at community learning center (Pusat Kegiatan Belajar Masyarakat) Setia Mandiri. Data was collected by using interviews, document studies, and direct observation. Framework to conduct this evaluation is based on CIPP model, Input, Process, Product) introduced by Daniel L. Stufflebeam and Shinkfield (1999).

\subsection{Procedure}

The procedure in this study is in accordance with the evaluation model of CIPP. The following components will be reviewed, 1) Context: program relevance and community support in the form of legal analysis, feasibility analysis, goal analysis, and SWOT analysis; 2) Inputs: managers, tutors, students, programs, and facilities; 3) Process: management process and learning process; 4) Product: academic achievement and program benefits. After collecting the components, evaluator used analysis system for measure the success of Paket $C$ program.

\subsection{Data Collection Technique}

Data collection techniques include observation, interviews and document studies. The details of the use of the technique are as follows: 1) Using an observation guide, a direct observation was conducted on the activities of manager and administration staffs, tutors (educator), and students, the running program (computer skill), the current infrastructures, the process of management, and the learning process; 2) Interviews obtained data/information on program relevance and community support on paket $C$ program. Interviews were conducted with the Foundation's founders, administrative departments, tutors, students, alumni and the community around; 3) Document Study is done to obtain data on information written Documentary studies are used to obtain profiles, vision and mission, school objectives, tutors data, students data, infrastructures data, schedule of activities, program relevance and community support as well as academic achievements and program benefits.

\subsection{Data Analysis Technique}

The data that have been obtained in the field will be analyzed through the process of data classification, categorization and conclusions. Details on each of the step is as followed: (Sugiyono, 2016, pp. 338): 1) Data Reduction; which summarizes, chooses the essentials, focuses on the essentials, searches for the theme and pattern, and discards those that are not need; 2) Data Display (Presentation Data); conducted in the form of brief descriptions, charts, relationships between categories, flowcharts and table criteria who evaluator made and should be an analysis; 3) Conclusion Drawing/Verification is a new finding that has not previously existed. The findings can be descriptions or descriptions of an object that was previously dim or dark so that once the research becomes clear, it can be a causal or interactive

relationship, hypothesis or theory. The relationship will appear with standard of evaluation criteria with low, medium or high category. 


\section{RESULTS AND DISCUSSION}

Table Unit of Analysis of the Achievement of Paket $C$ program at PKBM Setia Mandiri

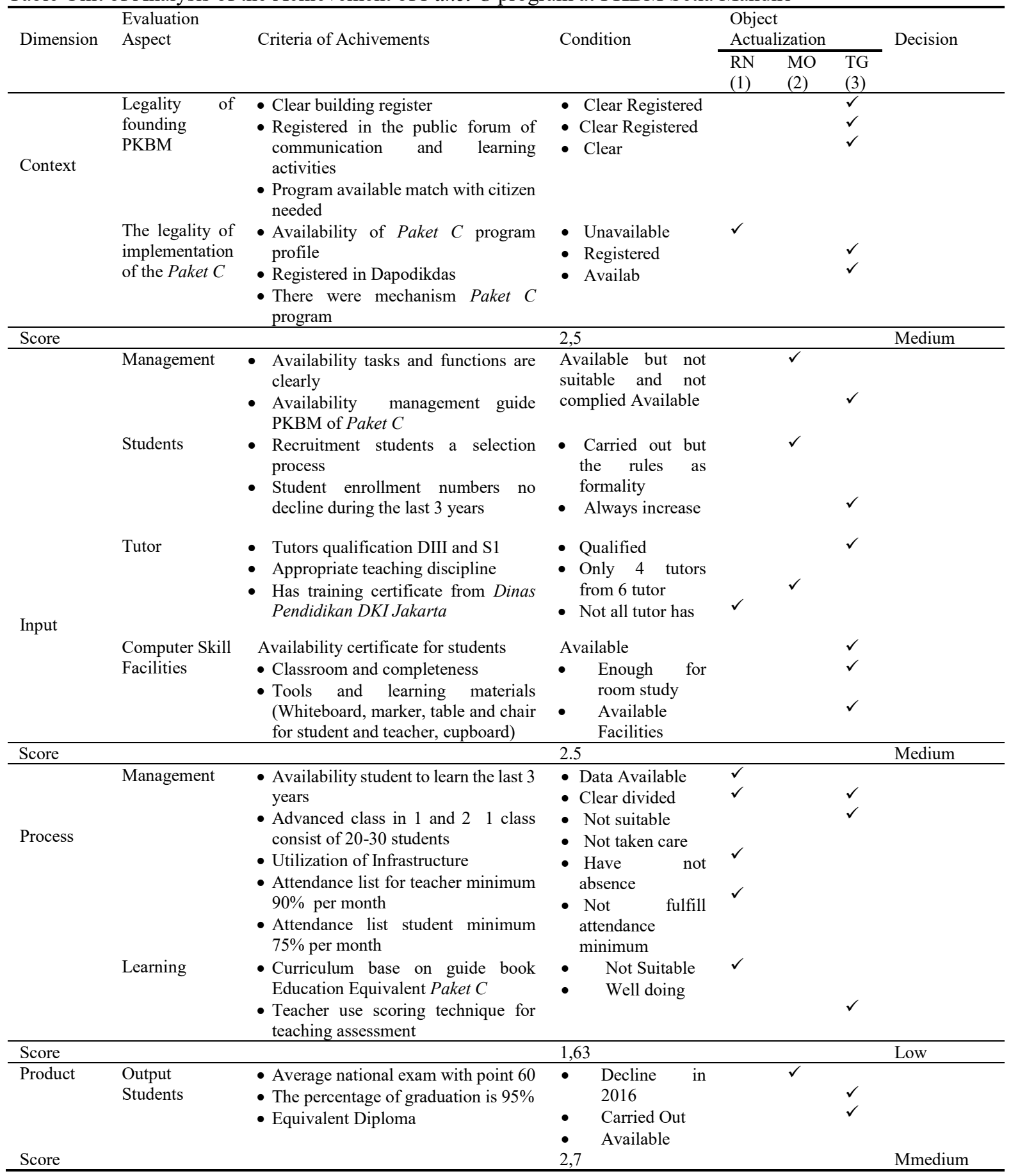


The calculation of achievement analysis of program evaluation, calculated based on:

Score Achieve x Option High Score

Acquire total actualization object achievements per step

High Score: acquire from totally options

Option : 3 is total from actualization object

RN : Rendah (Low) Score 1

MO : Moderat/ Sedang (Medium) Score 2

TG : Tinggi (High) score 3

\subsection{Context Dimension}

In a context acquire score 2.5 (medium). The legality aspect of implementing PKBM criteria with high actualization because all conditions or performance is clear and official existence. The legality aspect of Paket $C$ is said to be quite high against the lower part because the condition or performance more availability, while low category on the unavailability of Paket $C$ profile

\subsection{Input Dimension}

In an input acquire score 2.5 (Medium). The management aspect is said to be quite high due to problems with the task and function been exists, but not structured and systematically so this moderate is said to be an improvement to success. In aspects of learning are said to be quite high because the problem is on Human resources who do not carry out the selection process according to procedures, but procedures the selection is good so moderate this is said to have been stepped up success. The tutor aspect is said to be moderate to the low and high parts because in the moderate part that corresponds to more disciplines than on the unsuitable ones. So this moderate is more on the rise to success, while the lower part indicates that the certificate training is only owned by a small number of tutors, and its decisions show moderate. The aspects of computer program and the means of infrastructure demonstrate that decision high and should be maintained even improved.

\subsection{Dimension Process}

In a process acquire score 1.63 (Low). The management aspect is said to be quite low against the high part of the process management of the distribution of group of study exceeding the 20-30 per group of study rules, means complete facilities without intensive care, absence of absences which is binding for tutors as well as learning residents who do not meet the minimum presence for KBM. The learning aspect is said to be moderate, because the curriculum is used not in accordance with the guidelines and regulations of Ministry of Education and Culture numb. 14, 2007 about the standard content of Paket A, Paket B and Paket $C$. while the section high, teachers have their own assessment techniques to measure results learning citizens learn.

\subsection{Product Dimensions}

In a product acquire score 2.7 (Medium) Aspects of learners' learning outcomes are said to be quite high on the part moderate because the moderate part indicates a deterioration in the quality of the UN outcome year 2016 .

\section{CONCLUSIONS}

Based on the model offered by Daniel L Stuflebeam and Shinkfield that is CIPP models can be said that the existence of Paket $C$ program bring good impact on society. In the context dimension, the relevance of Paket $C$ program attendance in communities around Lebak Bulus area is very needed and becomes an important part of education that helps provide services equally to people with economic, geographic, demographic, and psychological backgrounds. In the input dimension, the elements involved are the chairman of the foundation, the head of the PKBM, the Administrator, the Tutor or the technical resource persons, and the students have activities that meet the standards of technical guidance. In other input dimensions, available infrastructure facilities have been met, and attracted the studying citizens must learn computer science as a form of skill provision of learning citizens. In the process dimension, the managerial system of the $\mathrm{C}$ package management program is not in accordance with the implementation standards in the aspects of planning, availability, maintenance and utilization of infrastructure. The learning process did not fully follow the provided curriculum, only focused on the discussion of UN material. In product dimension, the aspect of studying citizen has decreased the score of UN although every year its graduates more than $90 \%$. The certificate issued by paket $c$ has equal recognition to the formal education of the world of industry and the local community. 


\section{ACKNOWLEDGEMENTS}

The authors wish to thank Faculty of Education Sciences UIN Syarif Hidayatullah Jakarta.

\section{REFERENCES}

Adhiaty, M. (2012). Manajemen Program Kejar Paket C di PKBM Sarana Maju Kota Tegal. Lembaran Ilmu Kependidikan, 41(2).

Arikunto, S. (2006) Dasar-Dasar Evaluasi Pendidikan. Jakarta: PT Bumi Aksara. Edisi Revisi.

Arikunto, S., Jabar, C. S. A. (2009) Evaluasi Program Pendidikan - Pedoman Teoritis Praktis Bagi Praktisi Pendidikan. Jakarta: Bumi Aksara.

Buono. (2008). Evaluasi Pelaksanaan Program Paket C di Kota Yogyakarta. Thesis. Univesitas Gajah Mada.

Cordray, D. S. (1987). Evaluation Studies Review Annua, Volume 11. California: Sage Publication.

Dianti, R. R., Puteri., Sumarno. (2013). Evaluasi Pelaksanaan Program Paket C di PKBM Al- Muthi'in Banguntapan Bantul. Jurnal Evaluasi Pendidikan, 1 (1).

Dina, R. (2011). Evaluasi Program Kesetaraan Paket C pada Program Pusat Kegiatan Belajar Masyarakat (PKBM) Negeri 17 Penjaringan. Jakarta Utara. Tesis. Institut Pertanian Bogor.

Echols, J. M. (2016). Kamus Inggris - Indonesia. Jakarta: PT Gramedia Pustaka Utama.

Hizam, I. (2015). Evaluasi Program Penyelenggaraan MTsN Kediri Model CIPP. Jurnal Jurusan Pendidikan IPS Ekonomi, XIV.

Marzuki, S. (2012). Pendidikan Nonformal Dimensi dalam Keaksaraan Fungsional, Pelatihan, dan Andragogi. Bandung: PT. Remaja Rosdakarya.

Munthe, A. P. (2015). Pentingnya Evaluasi Program di Institusi Pendidikan: Sebuah Pengantar, Pengertian, Tujuan dan Manfaat. Jurnal Scholaria, 5(2).

Peraturan Menteri Pendidikan Nasional Republik Indonesia Nomor 14 Tahun 2007 tentang Standar Isi untuk Program Paket A, Program Paket B, dan Program Paket C.

Rossi, P. H., (1982). New Direction for Program Evaluation: Standar for Evaluation Practice. San Frasisco: Jossey-Bass.

Stufflebeam, D. L. (2002). International Handbook of Educational Evaluation. Springer International Handbook of Education.

Sudjana, D. (2016). Evaluasi Program Pendidikan Luar Sekolah. Bandung: PT. Remaja Rosdakarya.

Sugiyono. (2016). Metode Penelitian Pendidikan Pendekatan Kuantitaf, Kualitatif dan R\&D. Bandung: Penerbit Alafabeta.

Sukardi. (2011). Evaluasi Pendidikan Prinsip dan Operasionalnya. Jakarta: Bumi Aksara.

Syaodi, N. (2005). Metode Penelitian Pendidikan. Bandung : Remaja Rosdakarya.

Tayibnapis, F. Y. (2000). Evaluasi Program. Jakarta: PT. Rineka Cipta.
Tim Penyusun. (2010). Pedoman Penyelenggaraan Paket C Umum. Direktorat Pendidikan Kesetaraan Direktorat Jenderal Pendidikan non-Formal dan Informal.

Widoyoko, E. P. (2015). Evaluasi Program Pembelajaran Panduan Praktis Bagi Pendidik dan Calon Pendidik. Yogyakarta: Pustaka Pelajar. cet ke VII.

Zhang, et al, (2011). Guili. Using the Context, Input, Process, and Product Evaluation Model (CIPP) as a Comprehensive Framework to Guide the Planning, Impelementation, and Assesment of Service-Learning Programs. Journal of Higher Education Outreach and Engagement. 15(4), 59. 